\title{
Naringenin Enhances the Anti-Tumor Effect of Doxorubicin on HeLa Cervical Cancer Cells Through Cytotoxic Activity and Apoptosis Induction
}

\author{
Larasati, Indri Kusharyanti, Adam Hermawan, Ratna Asmah Susidarti, \\ Edy Meiyanto* \\ Cancer Chemoprevention Research Center, Faculty of Pharmacy \\ Universitas Gadjah Mada \\ Jalan Sekip Utara Sleman Yogyakarta 555281
}

\begin{abstract}
Naringenin, an abundant flavanon in the peel of citrus fruits is reported to possess antiproliferative effect in many cancer cells. Herein, we investigated the cytotoxic effect and apoptosis induction of naringenin in combination with doxorubicin on HeLa cells. The cytotoxicity assay of naringenin, doxorubicin, and their combination were carried out by using MTT assay. Cell viability was used as the parameters to evaluate combination effectiveness. Cell cycle distribution was determined by flow cytometry and analyzed using ModFit LT 3.0 program. Apoptosic assay was done by double staining method using Ethidium BromideAcridine Orange. Investigation on the expression of $\mathrm{Bax}$ and $\mathrm{Bcl}-2$ were determined by immunocytochemistry method. Naringenin and doxorubicin showed cytotoxic effect on HeLa cells with their $\mathrm{IC}_{50}$ values of $195 \mu \mathrm{M}$ and $\mathrm{I} \mu \mathrm{M}$, respectively. Whereas combination of naringenin-doxorubicin showed greater cytotoxicity compared the single treatment of doxorubicin. The strongest cytotoxic activity was observed at a combination of $100 \mu \mathrm{M}$ naringenin and 0,5 $\mu \mathrm{M}$ doxorubicin. Single treatment of $0,5 \mu \mathrm{M}$ doxorubicin for 24 hours on HeLa cells induced S-phase arrest while $100 \mu \mathrm{M}$ naringenin did not affect on HeLa cell cycle. The combination induced S-phase arrest with the increased of sub-GI phase percentage. In accordance with the flow cytometry results, the double staining apoptosis assay results showed the increase of apoptotic cells. Naringenin, doxorubicin, and their combination also increased the expression of Bax and decreased the expression of $\mathrm{Bcl}-2$. These results concluded that naringenin was a potential co-chemotherapy agent for cervical cancer due to its synergism with doxorubicin.
\end{abstract}

Keywords: co-chemotherapy, naringenin, doxorubicin, HeLa cells, cytotoxicity, cell cycle, apoptosis

\section{INTRODUCTION}

Cervical cancer is one of the most common cancer in women. Many efforts have been made to cure the disease, such as using chemotherapy agent doxorubicin. Doxorubicin is a first line chemotherapy agent for cervical cancer. The mechanism of doxorubicin is believed through intercalating DNA and promoting the cleavage of DNA by inhibition of DNA topoisomerase II. It is also able to induce apoptosis by activating caspase-3 (Wang et al., 2004). Its therapeutic use is, however, is limited due to the severe cardiotoxicity and development of cell resistance (Gangadharan et al., 2009). To overcome such problems, strategies must be devised to improve its effectiveness. The best approach is through cochemotherapy, by combining doxorubicin with natural chemopreventive substances.

One of them is naringenin, which had cytotoxic effect and caused cell death via apoptosis in various human cancer cells. The cytotoxic mechanism does not depend on p53, a tumor supressor gene (Kanno et al., 2005), so naringenin is promising cochemotherapy agent for cancer which has inactivated p53.

*Corresponding author e-mail: meiyan_e@ugm.ac.id 
Enhancing cell cycle arrest and apoptosis induction of cancer cells is promising target to cure cancer. Therefore, the present study was carried out to address the objective wether naringenin could enhance the efficacy of chemotherapy agent, doxorubicin via cell cytotoxicity, cell cycle arrest, and apoptosis induction.

\section{MATERIALS AND METHODS}

\section{Doxorubicin}

Doxorubicin (P.T. Ferron Par Pharmaceutical.) was diluted directly using culture medium DMEM right before treatment. The administered concentration series were $0,1-0,8$ $\mu \mathrm{M}$.

\section{Naringenin}

Naringenin (NGEN) (Sigma Aldrich) was dissolved in dimethyl sulfoxide (DMSO) (Sigma) as stock solutions and diluted as desired directly in the culture medium. The administered concentration series were $25-1000 \mu \mathrm{M}$.

\section{Cell Culture}

HeLa cervical cancer cells was obtained from Cancer Chemoprevention Research Center (CCRC)-UGM. Cells were grown in DMEM (Dulbecco's modified Eagle's medium) (Gibco) supplemented with $10 \%$ fetal bovine serum (Gibco) and 1\% Penicillin-Streptomycin (10.000 unit $/ \mathrm{ml}$ Penicillin and $10.000 \mu \mathrm{g} / \mathrm{ml}$ Streptomycin) (Gibco) and maintained in a humidified atmosphere containing $5 \% \mathrm{CO}_{2}$ at $37^{\circ} \mathrm{C}$. The cell was cultured in $10 \mathrm{~cm}$ tissue culture dish (Iwaki) and harvested using $0,25 \%$ Trypsin-EDTA (Gibco).

\section{Cytotoxic assay to analyze inhibition of HeLa cell proliferation}

Individual wells of 96-well plate (Iwaki) were inoculated with $100 \mu \mathrm{l}$ DMEM medium containing $5 \times 10^{3}$ cells. The plate was incubated for $24 \mathrm{~h}$ to achieve $60-70 \%$ confluence. Once the cells were confluent, treatment was conducted in accordance to pre-calculated concentrations. MTT reagent $(5 \mathrm{mg} / \mathrm{ml}$, dissolved in medium) was added to each well $24 \mathrm{~h}$ (single and combination treatment) and the plate was incubated for $3 \mathrm{~h}$ at $37^{\circ} \mathrm{C}$. After incubation, SDS $10 \% \mathrm{v} / \mathrm{v}$ in $\mathrm{HCl}$ was added to the wells followed by gentle shaking to dissolve the formazan dye. After an overnight incubation, the cell's absorbance was measured at
$595 \mathrm{~nm}$ with a plate reader. Single treatment of NGEN and DOX conducted first to determine $\mathrm{IC}_{50}$ value which was then used to set combination dosages. Cell viability and was used as the parameter to evaluate combination effectiveness.

\section{Flow cytometry assay to analyze HeLa cell cycle distribution}

Flow cytometry enables the identification of the cell distribution during the various phase of the cell cycle. The Hela cells ( $5 \times 10^{5}$ cells/well) were inoculated in 6-well plate the incubated for $24 \mathrm{~h}$. The cells were treated with selected dosage according to the cytotoxicity result for $24 \mathrm{~h}$. Two eppendorfs were prepared for each treatment, one for dead cells (I) and the other for living cells (II). To obtain the dead cells, the DMEM growth medium was collected into eppendorf I, centrifuged at $2000 \mathrm{rpm}$ for 3 minutes, and washed twice using PBS. To obtain the living cells, cells were harvested using trypsin-EDTA $0.25 \%$, collected into eppendorf II, centrifuged at 2000 rpm for 3 minutes, and washed using PBS. Cells inside the two eppendorfs were then combined, washed using cold PBS, centrifuged at $2000 \mathrm{rpm}$ for 30 second, and the supernatant was disposed. Flowcytometry reagent $(25 \mu \mathrm{l}$ propidium iodide, $2.5 \mu 1$ RNase, $0.5 \mu 1$ Triton-X in $500 \mu 1 \mathrm{PBS}$ ) was added, followed by incubation at $37^{\circ} \mathrm{C}$ for 10 minutes. The cell suspension were then filtered, transferred into a flow cytometer-tube and its cell cycle profile was read using Flow cytometer FACS-Calibur. Each cell cycle profile was analyzed using ModFit LT 3.0.

\section{Double staining apoptosis assay}

Acridine orange (AO) (Sigma)-ethidium bromide (EB) (Sigma) dual staining was used to identify apoptotic cells. Coverslips (Iwaki) were placed in 24-well plates (Iwaki) then $5 \times 10^{4} \mathrm{HeLa}$ cells were seeded to them, then incubated for $24 \mathrm{~h}$. Then, cells were treated with agent as described above (cytotoxicity result). Briefly, after incubation, medium was removed and cells were washed with PBS. Coverslips were removed into object glass, stained $10 \mu \mathrm{l} 1 \mathrm{x}$ working solution of $\mathrm{AO}-\mathrm{EB}$ and analyzed using fluorescence microscope (Zeiss MC 80). Apoptotic cells would be seen as reddish-orange fluorescence and viable (normal) cells would be seen as green fluorescence. 


\section{Analysis of Bax and Bcl-2 expression using Immunocytochemistry method}

Coverslips (Iwaki) were placed in 24-well plates (Iwaki) then $5 \times 10^{4} \mathrm{HeLa}$ cells were seeded to them, then incubated for $24 \mathrm{~h}$. Then, cells were treated with agent as described above in the cytotoxicity assay, and incubated for $18 \mathrm{~h}$. Culture medium were removed and cells were washed in PBS. Cells were fixed with cold methanol for 10 minutes and washed by PBS. Then, cells were added with $\mathrm{H}_{2} \mathrm{O}_{2}$ blocking solution for 10 minutes and removed. Cells were added with prediluted blocking serum for 10 minutes, removed, and incubated with monoclonal antibody anti-Bax (Sigma) or Bcl-2 (Enzo Life Science) for $2 \mathrm{~h}$. Then, cells were washed with PBS and incubated with biotinylated universal secondary antibody for 10 minutes, removed, and washed with PBS. Cells were incubated with streptavidin-peroxidase complex reagent for 10 minutes, removed, and washed with PBS. Cells were stained with substrate solution $\mathrm{DAB}$ for 10 minutes, removed, and washed with aquadest. Cells were stained with Mayer Haematoxylin for 3 minutes, removed, and washed with aquadest. Coverslips were moved into object-glass and fixed with ethanol and xylol.
After that, coverslips were added with mounting media and covered by other coverslips. Protein expression observed by microscope. Cells with positive $\mathrm{Bax}$ or $\mathrm{Bcl}-2$ expression appears in brown/dark, while cells with negative protein expression appears in blue/violet.

\section{RESULTS AND DISCUSSION}

Cytotoxic effect of naringenin (NGEN), doxorubicin (DOX), and their combination on HeLa cells

In order to assess the potential cell proliferation inhibition via cytotoxic effect of doxorubicin and naringenin, HeLa cells were treated with both samples and cell viabilities were determined by MTT assay. The result showed that $0,5 \mu \mathrm{M}$ doxorubicin (Fig. 1B) and $100 \mu \mathrm{M}$ naringenin (Fig. 1C) change the $\mathrm{HeLa}$ cell morphology compared to control (Fig. 1A). Doxorubicin and naringenin inhibited the growth of HeLa cells in dose-dependent manner (Fig. $1 \mathrm{D}$ an F) and $\mathrm{IC}_{50}$ of 24 hours time course were $1 \mu \mathrm{M}$ and $195 \mu \mathrm{M}$, respectively. 


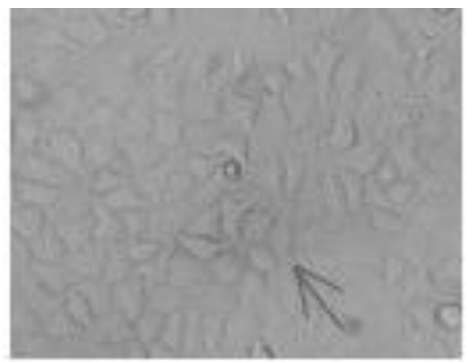

A

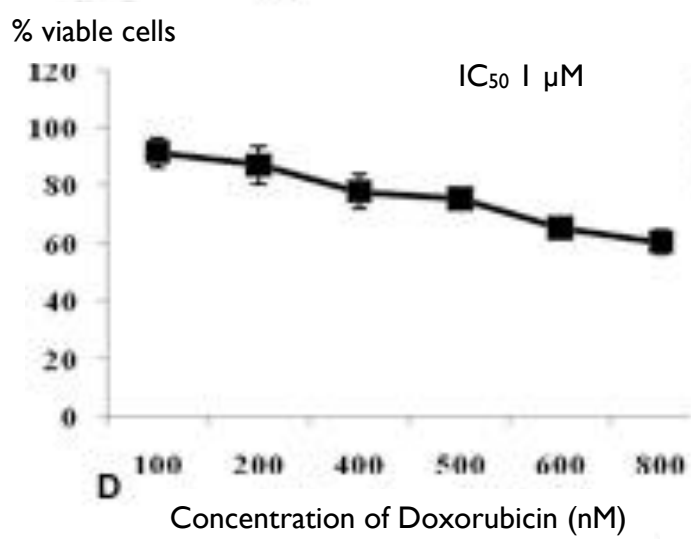

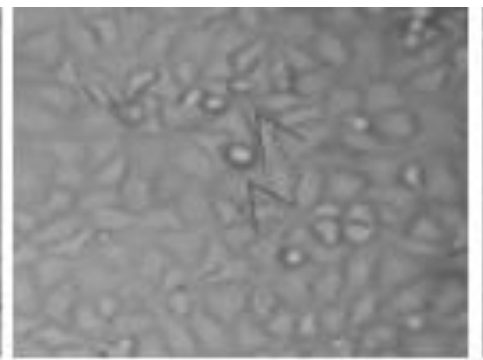

B

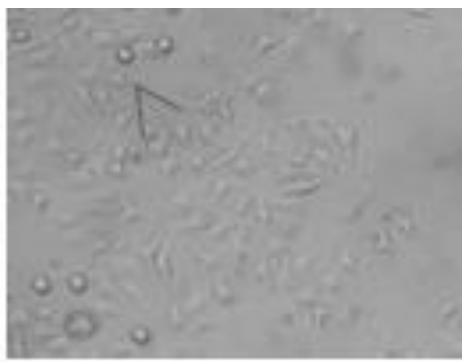

C

$\%$ viable cells

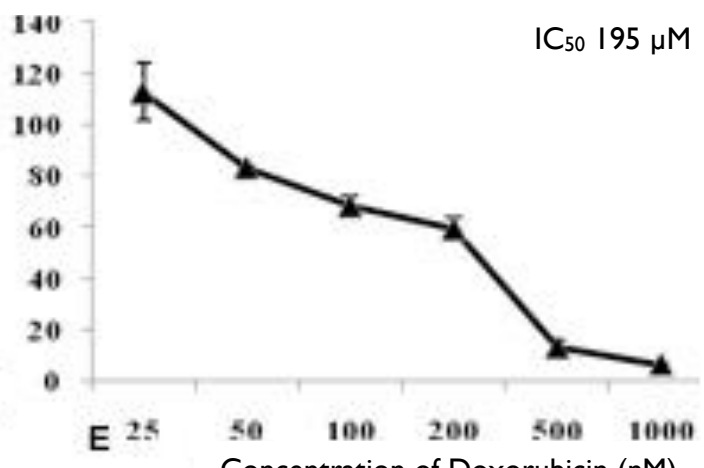

Concentration of Doxorubicin (nM)

$\%$ viable cells

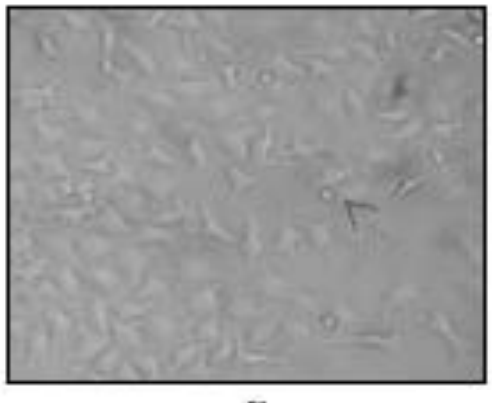

$\mathbf{F}$

Doxorubicin $(\mathrm{nm})$

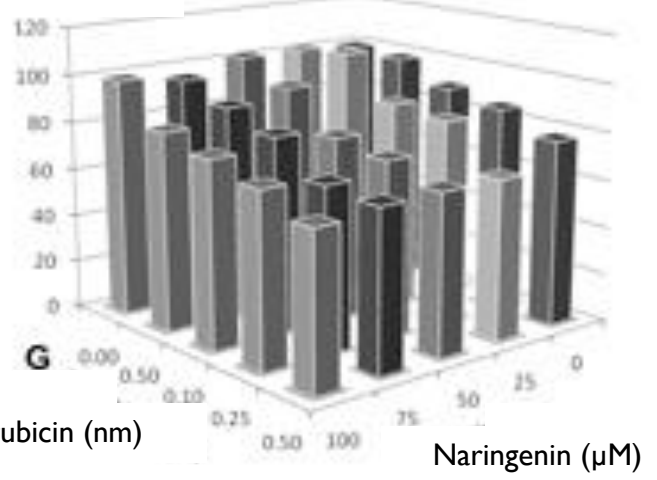

Figure I. Cytotoxic effect of DOX and NGEN on cervical cancer HeLa cells. Hela cells (5x/ $0^{3}$ cells/well) were plated in 96-well palte and $24 \mathrm{~h}$ after plating, the cells were treated with $\mathrm{DOX}(0,1-0,8 \mu \mathrm{M})$ and NGEN (25-1000 $\mu \mathrm{M})$ for $24 \mathrm{~h}$. (A) cell control. (B) cells with DOX 0,5 $\mu \mathrm{M}$. (C) cells with NGEN $100 \mu \mathrm{M}$. The percentage of cell viability were presented on graphic (E) for DOX and (F) for NGEN. Data were shown as mean \pm SD by 3 parallel experiment. The experiment was continued by conducting combination of DOX and NGEN on HeLa cells for $24 \mathrm{~h}$. (G) cells with $500 \mathrm{nM}$ DOX-50 $\mu$ M NGEN. (F) cells with 0,5 $\mu$ M DOX-100 $\mu$ M NGEN. The combination gave enhanced growth inhibitory effect on HeLa cells, shown in figure $(H)$. Original magnification was 100x. \& cells with morphological change.

The combination dosage of doxorubicin and naringenin was set corresponding to the results obtained from single treatment. The result showed that combination gave enhanced cytotoxic effect (Fig. $1 \mathrm{G}$ and F), as shown by further changing of cell morphology. The greatest cytotoxic effect was given by combination of $0,5 \mu \mathrm{M}$ doxorubicin- 100 $\mu \mathrm{M}$ naringenin (Fig. $1 \mathrm{~F}$ ). The cytotoxic result of combination application was greater than single application showed that combination of doxorubicin and naringenin was more effective than doxorubicin treatment alone on HeLa cells.

The morphological changes indicate cell death, which in turn corresponds with reduction of 
cancer cells proliferation. The antiproliferation mechanism of chemotherapy agent may be due to cell cycle arrest pathway. Thus, we conducted flow cytometry assay to investigate the cell cycle arrest effect of doxorubicin and its combination of naringenin on HeLa cells.

Effect of doxorubicin, naringenin, and their combination on cell cycle arrest induction of HeLa cells

The flow cytometry assay reveals distribution of cells in three major phases in cycle (G1, S, and G2/M) by determining cellular DNA content. The cell control of flow cytometry profile depicted normal cell cycle distribution (Fig. 2A) wherein the G1 phase takes up the longest time to progress. The cells treated with $100 \mu \mathrm{M}$ naringenin showed cell cycle distribution which was not noticeably different with the profile of cell control (Fig. 2B). Doxorubicin $0,5 \mu \mathrm{M}$ arrested the cell cycle at $\mathrm{S}$ phase as much $85,41 \%$ (Fig. 2C). The combination of $0,5 \mu \mathrm{M}$ doxorubicin- $100 \mu \mathrm{M}$ naringenin showed $\mathrm{S}$ arrest $(64,17 \%)$ with increased occurrence of sub-G1 phase $(14,35 \%)$ (Fig. 2D). The combination treatment resulted the higher level of cell death compare to the single treatment. To verify the indication of cell death by apoptosis of flow cytometry result, we also conducted apoptosis assay.

Effect of doxorubicin, naringenin, and their combination on apoptotic death of HeLa cells

Assessment of apoptotic cells was carried out under fluorescence microscope. Apoptotic cells would give reddish-orange fluorescence. The result showed both $0,5 \mu \mathrm{M}$ doxorubicin (Fig. 3B) and $100 \mu \mathrm{M}$ naringenin (Fig. 3C) induced apoptosis in $\mathrm{HeLa}$ cells and there was not apoptotic occurrence in cell control (Fig. 3A). Combination of $0,5 \mu \mathrm{M}$ doxorubicin- $100 \mu \mathrm{M}$ naringenin resulted the highest occurrence of apoptotic cells and the lowest density of cells (Fig. $3 \mathrm{D})$.
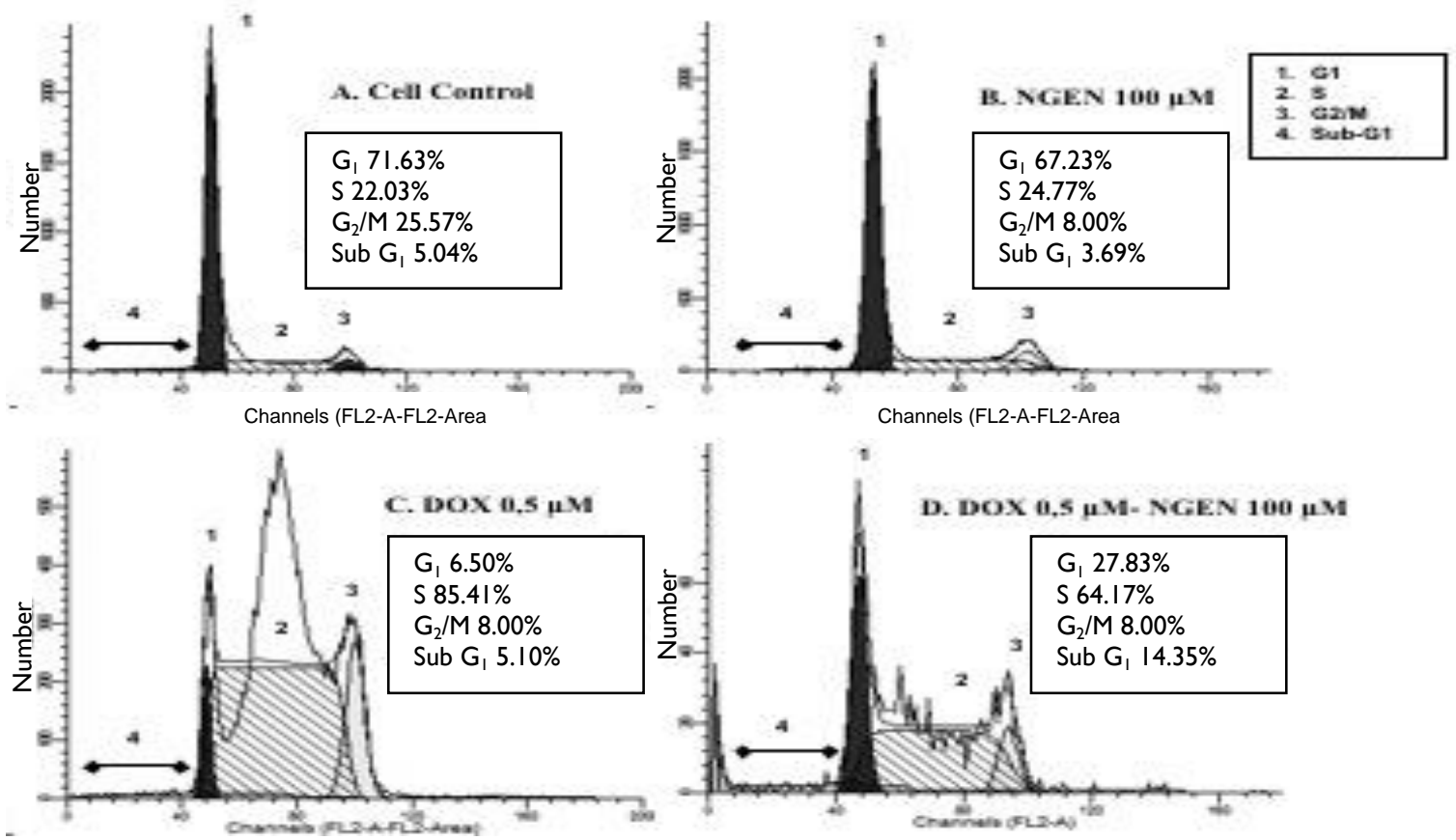

Channels (FL2-A-FL2-Area

Channels (FL2-A-FL2-Area

Figure 2. DOX and NGEN induced cell cycle arrest on cervical cancer HeLa cells. Hela cells ( $5 \times 10^{5}$ cells/well) were sedded in 6-well plate and $24 \mathrm{~h}$ after plating, the cells were treated with agents for $24 \mathrm{~h}$. (A) cell control. (B) cells with NGEN $100 \mu \mathrm{M}$. (C) cells with DOX 0,5 $\mu$ M. (D) cells with combination of 0,5 $\mu$ M DOX-I00 $\mu$ M NGEN. The cell cycle distribution assay was performed by flow cytometry. 


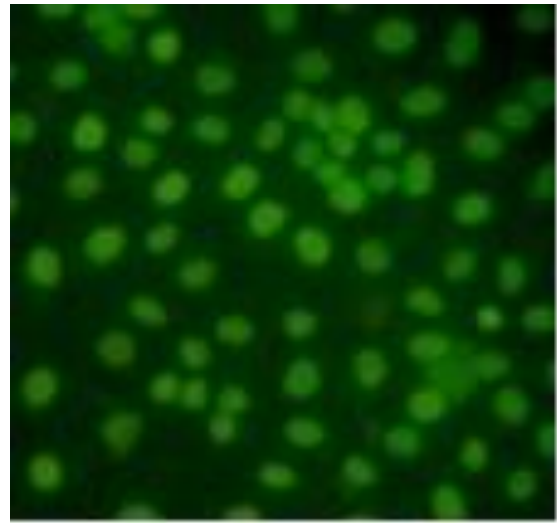

$\boldsymbol{A}$

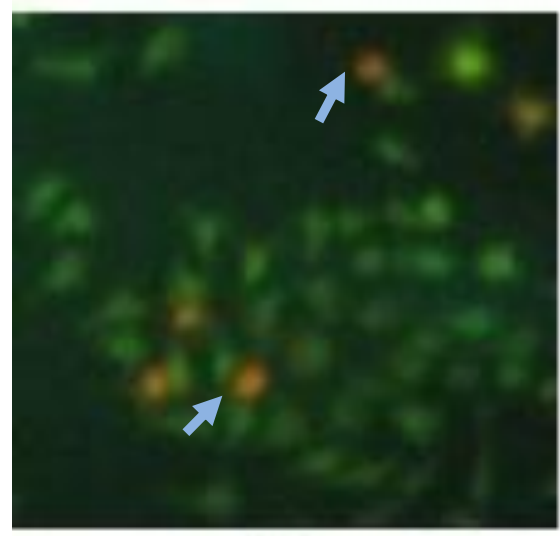

C.

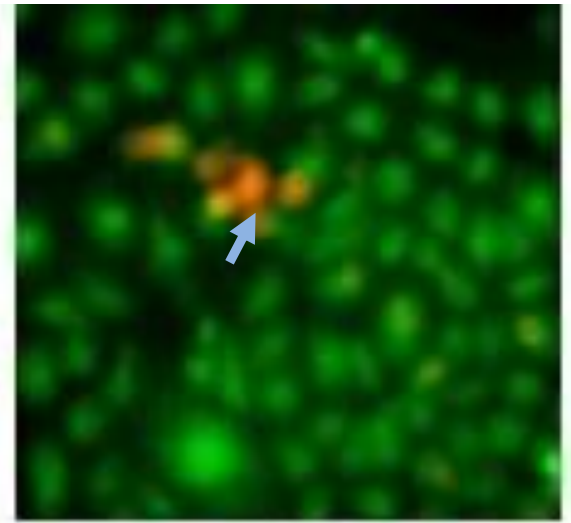

B

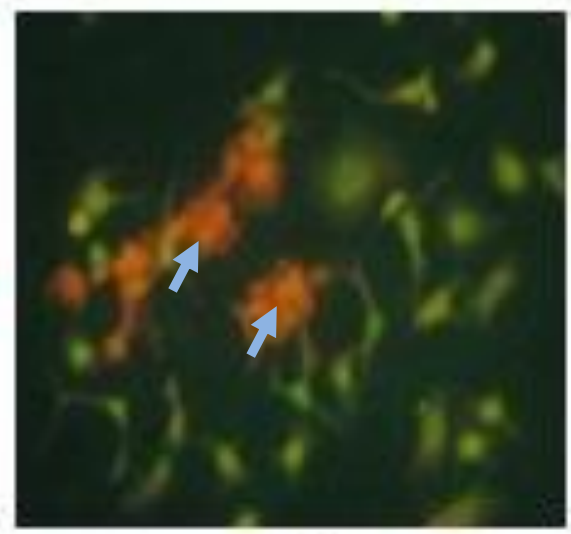

D

Figure 3. DOX and NGEN induced apoptosis on cervical cancer HeLa cells. Hela cells (5xI $0^{4}$ cells/well) were plated on coverslips in 24-well plate and $24 \mathrm{~h}$ after plating, the cells were treated with agents for $24 \mathrm{~h}$. (A) cell control. (B) cells with DOX 0,5 $\mu$ M. (C) cells with NGEN $100 \mu M$. (D) cells with combination of 0,5 $\mu$ M DOX-100 $\mu$ M NGEN. Apoptotis assay was conducted by acridine orange-ethidium bromide dual staining. Apoptotic cells were reddish-orange fluorescence and viable cells were green fluorescence. Original magnification was 400x. shows apoptotic cell.

Effect of doxorubicin, naringenin, and their combination on Bax and Bcl-2 expression of HeLa cells

Apoptosis is a complex cellular process involving multiple factors and steps biochemically. The balance of two cellular protein families, a pro- apoptotic protein Bax and an anti-apoptotic protein Bcl-2, influences a cell's fate through a intrinsic apoptotic pathway. Overexpression of Bax and downregulation of $\mathrm{Bcl}-2$ represents an actively apoptotic process in the cells. 


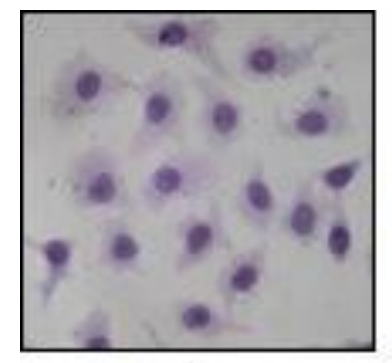

A

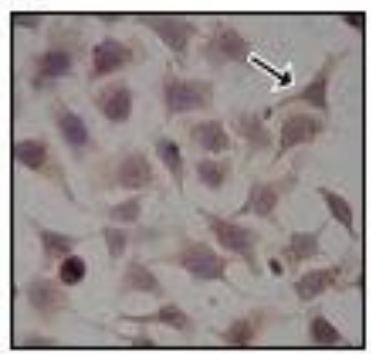

D

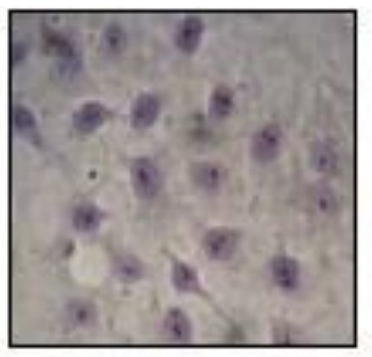

B

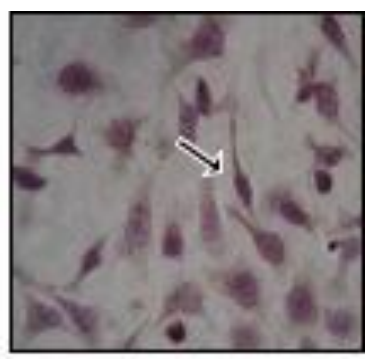

C

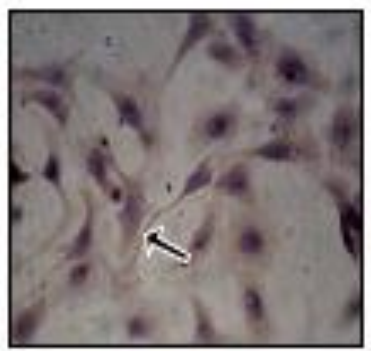

E.

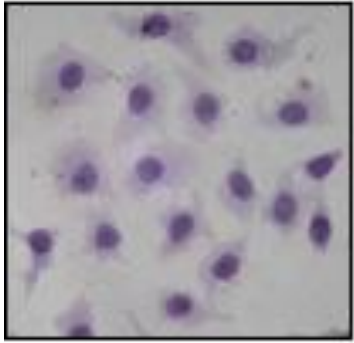

F

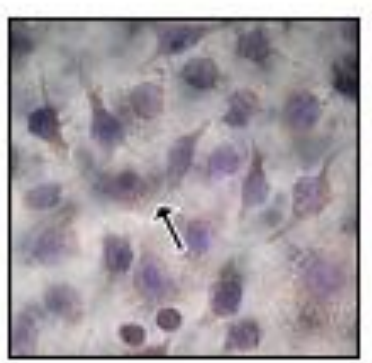

G

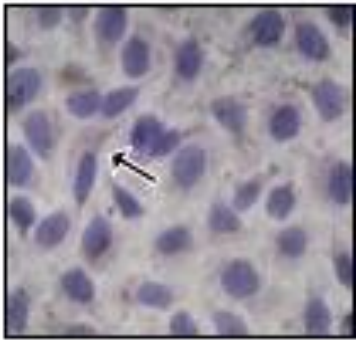

H

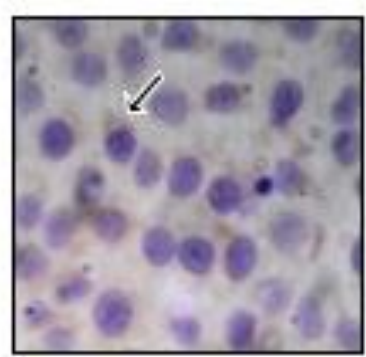

I

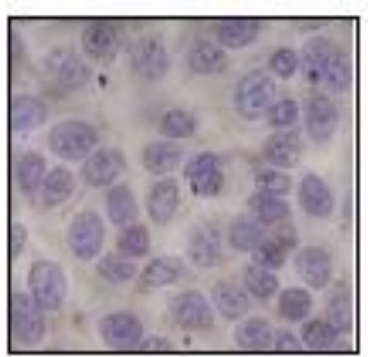

J

Figure 4. DOX and NGEN increased Bax expression and decreased Bcl-2 expression on Hela cells. Hela cells ( $5 \times 10^{4}$ cells/well) were seeded on coverslips in 24 -well plate and $24 \mathrm{~h}$ after plating, the cells were treated with agents for $18 \mathrm{~h}$. Pictures A-E are belong to cells given with Bax antibody. Pictures are F-J belong to cells given with $\mathrm{Bcl}-2$ antibody. (A and $\mathrm{F}$ ) cell control without $\mathrm{Bax}$ and Bcl-2 antibody. (B and $G$ ) cell control. (C and $H$ ) cells with DOX 0,5 $\mu$ M. (D and I) cells with NGEN $100 \mu \mathrm{M}$. (E and J) cells with combination of 0,5 $\mu$ M DOX-100 $\mu$ M NGEN. Original magnification was 400x. Cells expressed Bax or Bcl-2 showed brown color in cytoplasm.

The cell control showed no expression of Bax (Fig. 4B) and high expression of Bcl-2, indicated by intense appearance of brown color in cytoplasm (Fig. 4G). These are normal profile of HeLa cells because oncoprotein E6 could induce
Bax degradation on the cells. The cells treated with both DOX $0,5 \mu \mathrm{M}$ and NGEN $100 \mu \mathrm{M}$ performed Bax expression (Fig. $4 \mathrm{C}$ and D) and low Bcl-2 expression (Fig. $4 \mathrm{H}$ and I). Combination of 0,5 $\mu \mathrm{M}$ DOX-100 $\mu \mathrm{M}$ NGEN resulted the highest 
expression of Bax (Fig. 4E) and lowest expression of Bcl-2 (Fig. 4J). This is in accordance to the apoptosis result that cells treated with combination DOX-NGEN had the most apoptotic cells. From this result, we conclude that the combination of doxorubicin and naringenin increased Bax expression and decreased $\mathrm{Bcl}-2$ expression on HeLa cells better than its single treatment.

Doxorubicin and naringenin had the ability to inhibit proliferation of HeLa cervical cancer cell. Dosage increase corresponds to an increase in the antiproliferative effect. When doxorubicin was combined with naringenin, the cell proliferation inhibition activity increased significantly compared with their single treatment. The combination showed cytotoxicity synergism. This result support our hypothesis that naringenin is a promising agent to be combined with doxorubicin to improve its chemotherapy effectiveness.

The antiproliferative mechanism may be due to a cell cycle arrest pathway. Our data resulted that treatment of doxorubicin arrested $\mathrm{HeLa}$ cells in $\mathrm{S}$ phase while the treatment of naringenin did not affect the HeLa cell cycle. S phase arrest of doxorubicin is estimated caused by the ability of doxorubicin induce Chk1 phosphorylation (Beckermann et al., 2009). Naringenin could bind Cdk2 on its ATP binding site so could increase the doxorubicin ability to modulate HeLa cell cycle. Cdk2 is produced in late G1 phase and participated in transition of G1/S phase until $\mathrm{S}$ phase progression (Adina et al., 2008). Inhibition of Cdk2 action by binding with substance would induce cell cycle arrest to let the cells repair itself, or the cell would undergo apoptosis. The combination of doxorubicin and naringenin induced $\mathrm{S}$ arrest, which meant there is dominant influence of doxorubicin. The interesting phenomenon was the combination also increase the percentage of sub-G1 peak which indicated the increase of cell death.

Our data resulted both doxorubicin and naringenin induced apoptosis in $\mathrm{HeLa}$ cells via mitochondrial pathway. Doxorubicin induces apoptosis in cancer cells via activation of caspase 3 , effector of apoptosis pathway, and followed by DNA fragmentation (Wang et al., 2004). Reactive oxygen species might act as the signal molecules for doxorubicin induced apoptosis and the process is still functional even in the absence of p53. Through ROS pathway, doxorubicin could increase Bax expression and decreased Bcl-2 expression (Tsang et al., 2003). Naringenin induced apoptosis in T47D cells, cells with mutated p53 (Junedi et al., 2010). Naringenin also induced apoptosis via activation of caspase 3 and caspase 9 (Jin et al., 2009), increased bax expression and decrease Bcl-2 expression (Park et al., 2008). In accordance with our result, these research suggest that naringenin perform synergism effect with doxorubicin to induce apoptosis. However, further study about apoptosis molecular pathway via activation of caspase 3 is needed to determine the claim.

Doxorubicin usage is restricted by the development of resistance to apoptosis. Nuclear transcription factor kappaB (NF- $\mathrm{kB}$ ) has been shown both to block apoptosis and to promote cell proliferation, and hence has been considered as an important target for anticancer drug development (Gangadharan et al., 2009). Long term usage of doxorubicin also activates cell survival pathway PI3K/Akt (Li et al., 2005). Naringenin could

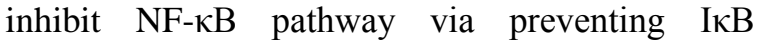
degradation (Yoshida et al., 2010). Naringenin also inhibited cell survival pathway by binding ATP on PI3K binding site (Hastuti et al., 2008). Through that mechanism, naringenin is expected to solve doxorubicin cell resistance problem. This research showed that doxorubicin and naringenin combination has good potency as candidate cochemotherapy agent for curing cervical cancer. Furthermore, the study about anticancer effect of the combination doxorubicin and naringenin needs to be continued.

\section{CONCLUSION}

Naringenin enhances the anti-tumor activity of doxorubicin on Hela cervical cancer cells through cytotoxic activity, cell cycle modulation, and apoptosis induction. Naringenin is a potential co-chemotherapy agent for cervical cancer due to its synergism with doxorubicin.

\section{ACKNOWLEDGEMENT}

We express our gratitude to Hibah Tim Pascasarjana Multitahun 2009-2010 Universitas Gadjah Mada and Cancer Chemoprevention Research Center who funded and supported this research.

\section{REFFERENCES}

Adina, A.B., Handoko, F.F., Setyarini, I.I., Septisetyani, E.P., Riyanto, S. and 
Meiyanto, E., 2008, Ekstrak Etanolik Kulit Jeruk Nipis (Citrus aurantifolia (Cristm.) Swingle) Meningkatkan Sensitivitas Sel MCF-7 terhadap Doxorubicin, Prosiding Kongres IImiah XVI ISFI 2008, 55-62, ISBN: 978-979-95 I08-6-0.

Beckerman, R., Donner, A.J., Mattia, M., Peart, M.J., Manley, J.L., Espinosa, J.M. and Prives, C., A Role for Chkl in Blocking Transcriptional Elongation of p2I RNA during the S-phase Checkpoint, Genes Dev., 23(II), I364-I377.

Gangadharan, C., Thoh, M. and Manna, S.K., 2009, Inhibition of Constitutive Activity of Nuclear Transcription Factor KappaB Sensitizes Doxorubicin-resistant Cells to Apoptosis, J. Cell. Biochem., 107, 203-2I3.

Hastuti, N., Pratiwi, D., Armandari, I., Nur, N., Ikawati, M., Riyanto, S. and Meiyanto, E., 2008, Ekstrak Etanolik Kulit Buah Jeruk Nipis (Citrus aurantifolia (Cristm.) Swingle) Menginduksi Apoptosis pada Sel Payudara Tikus Galur Sprague Dawley Terinduksi 7,12-Dimetilbenz[a]antrasen, Prosiding Kongres IImiah XVI ISFI 2008, 94-99, ISBN: 978-979-95 I08-6-0.

Hsiao, Y.C., Hsieh, Y.S., Kuo, W.H., Chiou, H.L., Yang, S.F., Chiang, W.L. and Chu, S.C., 2007, The Tumor-Growth Inhibitory activity of Flavanone and 2'-OH Flavanone in Vitro and in Vivo through Induction of Cell Cycle Arrest and Suppression of Cyclins and CDKs, J. Biomed. Sci., I4(I), 107-109.

Junedi, S., Susidarti, R.A. and Meiyanto, E., 2010, Peningkatan Efek Sitotoksik Doxorubicin oleh Naringenin pada Sel Kanker Payudara T47D melalui Induksi Apoptosis, JIFI, 8(2), 85-90.

Kanno, S., Tomizawa, A., Hiura, T., Osanai, Y., Shouji, A., Ujibe, M., Ohtake, A., Kimura,
K. and Ishikawa, M., 2005, Inhibitory Effects of Naringenin on Tumor Growth in Human Cancer Cell Lines and Sarcoma S- I80-Implanted Mice, Biol. Pharm. Bull., 28(3), 527-530.

Li, X., Lu, Y., Liang, K., Liu, B. and Fan, Z., 2005, Differential responses to Doxorubicininduced Phosphorylation and Activation of Akt in Human Breast Cancer Cells, Breast Cancer Res., 7, 589-597.

Park, J.H., Jin, C.-Y., Lee, B.K., Kim, G.-Y., Choi, Y.H. and Keong, Y.K., 2008, Naringenin Induces Apoptosis Through Downregulation of Akt and Caspase-3 Activation in Human Leukemia THP-I cells, Food Chem. Toxicol., 46, 3684-3690.

Tsang, W.P., Chau, S.P.Y., Kong, S.K., Fung, K.P. and Kwok, T.T., 2003, Reactive Oxygen Species Mediate Doxorubicin Induced p53-Independent Apoptosis, Life Sci., 73(I6), 2047-2058.

Vayssade, M., Haddada, H., Laurens, L.F., Tourpin, S., Valent, A., Benard, J. and Ahomadegbe, J.C., 2005, p73 Functionally Replaces p53 in Adriamycin-treated, p53deficient Breast Cancer Cells, Int. J. Cancer, I I6, 860-869.

Wang, S., Konorev, E.A., Kotamraju, S., Joseph J., Kalivendi, S. and Kalyanaranam, B., 2004, Doxorubicin Induces Apoptosis in Normal and Tumor Cells via Distinctly Different Mechanism, J. Biol. Chem., 279(24), 25535-25543.

Yoshida, H., Takamura, N., Shuto, T., Ogata, K., Tokunaga, J., Kawai, K. and Kai, H., The Citrus Flavonoid Hesperitin and Naringenin Block The Lipolytic Actions of TNF- $\alpha$ in Mouse Adipocytes, Biochem. Biophys. Res. Commun., 394(3), 728-732. 